\title{
MOTIVACE K UČENÍ SE ANGLIČTINĚ VE VZTAHU KE ZNÁMKÁM A STUDIJNÍM ASPIRACÍM U ŽÁKŮ ZÁKLADNÍCH ŠKOL
}

\author{
ENGLISH LEARNING MOTIVATION \\ IN RELATION TO GRADES \\ AND STUDY ASPIRATIONS AMONG \\ LOWER SECONDARY STUDENTS
}

\author{
ONDŘEJ PAPAJOANU, \\ HANA VOŇKOVÁ, \\ KATEŘINA VLČKOVÁ
}

\begin{abstract}
Abstrakt

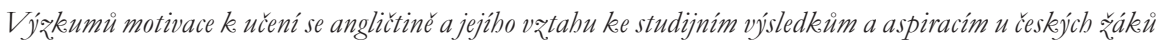
je málo. Tato studie si klade za cíl identifikovat vątah mezi úrovni výkonové motivace v anglićtinè a vybra-

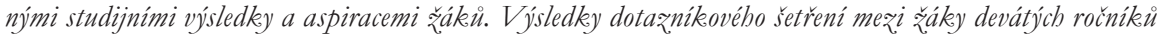
základnich škol ( $N=324$ ) ukazuji, že potřeba úspěsnébo výkonu (PÚV) v angličtinè je pozitivnim prediktorem a potřba vyhnuti se neúspèchu (PVN) v angličtinè negativním prediktorem v̌sech následujicich indikátori: známky z angličtiny na vysvédǐeni, získáni vyznamenání, budouci aspirace žákè studovat na gymnáziu. Pro chlapce byl efekt PÚV na tyto indikátory v prüméru nižši a naopak efekt PVN byl v prümèru vyšš než pro divkey, nicméné v rámci regresni analýzy se ukázalo, že efekty nejsou statisticky signifikantni. Potvrzeni těch to zjištèni vyžaduje dalši vỹzkum, který by bral v úvahu rozdily v uživáni škéal mezi žáky (např̀ skerze aplikaci metody ukotvujicich vinèt).
\end{abstract}

\section{Klíčová slova}

motivace, studijni výsledky, studijni aspirace, angličtina jako ciži jazyke, nižši sekundárni vądèlávání

\begin{abstract}
Studies on student motivation to learn English as a foreign language (EFL) and its relationship to achievement and study aspirations among $C$ zech students are scarce. This study aims to identify the relationship between student level of EFL achievement motivation and their achievement and study aspirations. The results of a survey among ninth-grade basic school students $(N=324)$ show that the need for achievement $(N f A)$
\end{abstract}


in EFL is a positive predictor and the need to avoid failure (NtAF) is a negative predictor of their final grade in English, of receiving a final report card with honors, and of aspiration to study at a grammar school. The effect of NfA on all indicators was, on average, lower for boys than for girls, and the effect of NtAF for boys was, on average, higher, yet the regression analysis showed that the effects were not significant. Further research should reflect the differences in scale usage among students (e.g., by using the anchoring vignette method).

\section{Keywords}

motivation, achievement, study aspirations, English as a foreign language, lower secondary education

\section{Úvod}

Motivace je považována za jeden z klíčových faktorů souvisejících s mírou úspěšnosti při učení se cizímu jazyku a zejména $\mathrm{v}$ posledních letech se těší velké pozornosti výzkumníků (Boo et al., 2015; Lamb, 2017). Studie zabývající se motivací k učení se cizím jazykům opakovaně dokládají vztah mezi motivací a mírou reportovaného motivovaného chování vztahujícího se k učení se danému jazyku (např. Kong et al., 2018; Papi, 2010) či s úrovní dovedností respondentů v daném jazyce (např. Khodadady \& Khajavy, 2013; Pae, 2008).

Ukazuje se také, že motivace k učení se cizímu jazyku se může lišit v závislosti na mnohých charakteristikách respondentů, jako je např́íklad pohlaví (Azarnoosh \& Birjandi, 2012; Mori \& Gobel, 2006), věk (Kormos \& Csizér, 2008) nebo typ instituce, na které respondent studuje (You \& Dörnyei, 2016).

Informace o tom, jaké existují rozdíly mezi různými skupinami žáků v míre a struktuře jejich motivace $\mathrm{k}$ učení se cizím jazykům, jsou důležité i pro samotné pedagogy. Řada studií se v poslední době zaměřje na motivaci nejen z teoretického hlediska, ale zabývá se i některými praktickými aspekty, jako je zvyšování žákovské motivace k učení se cizím jazykům (Boo et al., 2015; Lamb, 2017). Důležitou roli v tomto mohou hrát právě pedagogové, kteří mají k dispozici celou řadu motivačních strategií (Lamb, 2017), jež mohou na základě poznání motivačních potřeb žáků aplikovat ve snaze adekvátně rozvíjet motivaci k učení se cizím jazykům u všech žáků a pomoci jim dosáhnout co nejlepších výsledků. Přesná identifikace rozdílů v úrovni motivace a jejího vztahu k studijním výsledkům a aspiracím u různých skupin žáků je tak podstatným úkolem pro výzkumníky. 
Teoretická východiska výzkeumu motivace ke učeni se cizím jazykimm a jejich vývoj Teoretický vývoj v oblasti výzkumu motivace k učení se cizím jazykům má dlouhou historii a obvykle se rozděluje do tř́ etap (Boo et al., 2015; Dörnyei, 2005). Od konce padesátých až do počátku devadesátých let dvacátého století byl výzkum motivace založen na sociálně psychologickém pohledu a na práci Roberta Gardnera a jeho kolegů, kteří se zabývali jazykovou situací mezi anglofonní a frankofonní populací v Kanadě (Dörnyei, 2005). Dle Gardnera tak značná část výsledků při učení se cizímu jazyku souvisela s tzv. integrativním motivem, tedy určitou snahou naučit se jazyk ceněné cizojazyčné komunity s cílem umožnit komunikaci s touto skupinou (Gardner et al., 1976).

Gardnerova teorie byla dominantním modelem motivace v oblasti učení se cizímu jazyku po více než 30 let (Dörnyei, 2005). Dodnes používaným výzkumným nástrojem je Gardnerova The Attitude/Motivation Test Battery (Gardner, 1985), která zahrnuje řadu škál zachycujících různé aspekty učení se cizímu jazyku (např. postoje k učení se danému cizímu jazyku, touhu učit se daný cizí jazyk).

V devadesátých letech dvacátého století začal výzkum motivace čerpat především z kognitivních teorií z pedagogické psychologie (Dörnyei, 2005). Za klíčové bylo považováno zejména to, jak jedinec přemýšlí o svých schopnostech, možnostech, potenciálu, limitacích, ale rovněž o různých aspektech cílů, o které usiluje (Dörnyei, 2005). Významnou motivační teorií, která by se dala zařadit do této etapy, je tzv. sebedeterminační teorie (Self-Determination Theory; Noels et al., 2000). Tato teorie je známá především pro své rozlišení mezi intrinsickou motivací (učím se, protože si užívám samotný průběh učení) a extrinsickou motivací (neučím se kvưli učení se samotnému, mám nějaký jiný, více či méně externí motiv; Lamb, 2017).

Dvacáté první století je pak charakteristické posunem zájmu výzkumníků směrem ke kontextuálním a dynamickým aspektům motivace (Boo et al., 2015). Dörnyei (2005) v souvislosti s tímto obdobím hovoří o tzv. na proces orientovaném př́stupu či paradigmatu (process-oriented approach/paradigm). Jak autor popisuje, motivace má dynamickou povahu a mění se v čase. Tyto změny lze pozorovat jak $\mathrm{v}$ rámci krátkých časových úseků, jako je hodina cizího jazyka ve škole, tak v rámci delších časových úseků (učení se jazyku po dobu několika měsíců či let). Motivace tak není vnímána jako statická vlastnost, ale jako určitý dynamický faktor, který se stále proměňuje. Dörnyei a Ottó (Dörnyei, 2005) v tomto kontextu představili svůj procesní model motivace $\mathrm{k}$ učení se cizímu jazyku (process model of L2 motivation). V tomto modelu je proces motivace rozdělen do několika časových úseků, které popisují, jak se úvodní přání a touhy transformují v cíle a následně v operacionalizované záměry a jak jsou ty to záměry realizovány, což vede (v lepším př́ípadě) $\mathrm{k}$ dosažení cílů následovaném finálním zhodnocením tohoto procesu. 
V roce 2005 pak byla poprvé představena v současné době dominující teorie motivace k učení se cizímu jazyku tzv. L2 Motivational Self System [L2MSS] (Boo et al., 2015; Dörnyei, 2009). Výsledky studií Dörnyeiho a jeho kolegů ukazovaly, že centrální úlohu v motivaci k učení se cizímu jazyku má tzv. integrativita (integrativeness), tedy touha naučit se cizí jazyk ceněné komunity, abych mohl komunikovat s jejími členy a stal se jim více podobný (Dörnyei, 2009). Pochybnosti o využitelnosti tohoto konceptu pro vysvětlování motivace $\mathrm{k}$ učení se cizím jazykům (tento koncept např́ílad nebylo možné dobře aplikovat $\mathrm{v}$ takových situacích, kdy je cizí jazyk vyučován ve škole a žákům chybí přímý kontakt s mluvčími daného cizího jazyka) vedly v kontextu tzv. teorie možných já (possible selves; Markus \& Nurius, 1986) k jeho reinterpretaci. Koncept integrativity byl reinterpretován jako specifický aspekt tzv. ideálního já, což se stalo hlavním prvkem této nové teorie (Csizér \& Dörnyei, 2005; Dörnyei, 2009).

L2MSS má ve své současné konceptualizaci tři hlavní složky: (1) ideální cizojazyčné já (Ideal L2 self) - tato složka reflektuje žádoucí obraz sebe sama jako takového uživatele daného cizího jazyka, jakým by se jedinec v ideálním př́padě chtěl v budoucnu stát (You et al., 2016); (2) závazkové cizojazyčné já (Ought-to L2 self) - tato složka reflektuje vlastnosti, o kterých se jedinec domnívá, že by měl mít, aby splnil očekávání druhých a vyhnul se možným negativním důsledkům (Dörnyei, 2009); (3) zkušenost s učením se cizímu jazyku (L2 Learning experience) - tato složka reflektuje motivy vážící se k učebnímu prostředí a dosavadním zkušenostem jedince, mezi které např́íklad patří vliv učitele, kurikula, vrstevníkủ či předchozí prožitky úspěchu (Dörnyei, 2009).

I přes dominanci L2MSS ukazuje systematická přehledová studie autorů Boo et al. (2015), že v současné literatuře figuruje více teoretických koncepcí motivace a značná část studií užívá koncepty vycházející z vícero těchto koncepcí.

\section{Studie zabývajici se motivaci k učení se cizím jazykuim v České republice} Studium různých aspektů motivace v oblasti vzdělávání má v české odborné literatuře dlouhodobé zastoupení (např. Jedinák, 1993; Pavelková \& Frencl, 1997; Pavelková et al., 2010; Trna, 1996). Literatury zabývající se motivací k učení se cizím jazykům nebo př́mo angličtině u českých žáků a studentů je však oproti té zahraniční pomálu.

Např́iklad Bronec (1991) se zabýval motivací k učení se cizím jazykům $\mathrm{z}$ teoretického hlediska a pojednává o různých motivech $\mathrm{k}$ učení se těmto jazykům v kontextu vysokoškolského studia. Janíková (2016) se zaměřovala na identitu jedince v kontextu cizích jazyků a jejich výuky. Motivace ve vztahu k učení se jazykům je v článku autorky zmiňována jako oblast výuky cizích jazyků, kde se konstrukt identity výrazně odráží. 
Knihová a Hronová (2015) se zabývaly motivací ke studiu cizího jazyka v kontextu organizace kurzů cizího jazyka a volby výukových nástrojů a metod. Dále Smejkalová (2016) se zaměřovala na metodu simulace v cizojazyčné výuce. Na základě dotazníkového šetření mezi univerzitními studenty autorka uvádí, že více než $50 \%$ studentů vykazuje silnou anebo velmi silnou úroveň motivace studovat cizí jazyk a že metodu simulace preferují studenti se silnou až velmi silnou motivací učit se danému cizímu jazyku.

Pavlíková (2015) se ve svém př́spěvku zaměřovala na využití informačních a komunikačních technologií ve výuce odborného cizího jazyka na vysoké škole. Autorka na základě výpovědí účastníků studie (univerzitní studenti) shrnuje, že návrh učebních aktivit s využitím webových služeb je př́nosný např́klad díky možnostem rozvoje produktivních jazykových dovedností, posílení motivace studentů či rozvoji dovedností potřebných pro týmovou práci. Pecková (2015) se pak zabývala možnostmi využití předmětu fiktivní firma jako prostředku osvojování cizích jazyků. Mezi zjištěními autorky patř́i např́iklad mimo jiné to, že žáci, kteří používají angličtinu při komunikaci se svými zahraničními obchodními partnery, nevykazují (až na strachovou motivaci) vyšší míru motivace učit se cizím jazykům.

Př́spěvek Frydrychové Klímové a Poulové (2015) pojednává o informačních a komunikačních technologiích a o jejich využití jako motivačního prvku při výuce anglického jazyka. Autorky prezentují aktivity, v rámci kterých čeští žáci základních škol komunikovali skrz internet s učiteli z Filipín, a reportované zkušenosti slovenských učitelů angličtiny s implementací technologií do výuky. Kozáková (2013) pak pojednává o motivačních pohybových aktivitách ve výuce ruského jazyka na druhém stupni základních škol a představuje soubor těchto aktivit vhodných pro začátečníky a mírně pokročilé žáky.

Kubíková a Kostelníková (2017) se zabývaly možnými příčinami nízké motivace některých žáků ke studiu německého jazyka na vybraných stř̌edních školách v Plzeňském kraji. Autorky na základě své výzkumné sondy poukazují na některé negativní postoje $\mathrm{k}$ německému jazyku a shrnují, že učitelé v jejich výzkumu bojují s nízkou motivací ke studiu tohoto jazyka. Tu připisují spíše vnějším aspektům (nap̌r. nematuritní předmět), které nemohou sami ovlivnit. V rámci výzkumu Frydrychové Klímové (2011) byl studentům vysoké školy předložen dotazník s otázkami, jež se týkaly motivace k učení a strategie učení se angličtině. Výsledky ukázaly, že všichni z dotazovaných studentů považují znalost angličtiny za důležitou pro svoji budoucnost.

Vlčková (2007) se ve své knize zaměřené na strategie učení cizímu jazyku částečně věnovala i žákovské motivaci k učení se cizím jazykům. Na vzorku 606 žáků brněnských gymnázií autorka zjistila, že 99 \% celého výzkumného souboru se učí anglicky, $70 \%$ německy, $19 \%$ francouzsky a $18 \%$ rusky. Angličtina byla také nejčastěji uváděným preferovaným cizím jazykem (79 \%), 
následovala němčina (13\%), francouzština (3\%) a ruština (2\%). Pokud jde o motivy pro učení se preferovanému cizímu jazyku, uváděli žáci především budoucí kariéru (75\%), povinnou maturitu z cizího jazyka (65\%), cestování (64\%) anebo že je pro ně důležité být v daném jazyce úspěšný (53 \%).

V knize Vlčkové et al. (2014) pak autoři na vzorku 462 žáků devátých ročníků základních škol v Jihomoravském kraji zkoumali učební a výkonovou motivaci žáků v anglickém jazyce a jejich vztah k studijním výsledkům. Bylo zjištěno, že žáci s vyšší učební motivací mají lepší známku z anglického jazyka a lepší skóre $\mathrm{v}$ testu z angličtiny a naopak. Výsledky dále ukázaly, že žáci s vyšší potřebou úspěšného výkonu v angličtině mají lepší známky z anglického jazyka $\mathrm{i}$ lepší výsledky v testu z angličtiny. Oproti tomu žáci s vyšší potřebou vyhnutí se neúspěchu v angličtině mají horší známku z angličtiny i nižší skóre v testu. Studie Vlčková (2007) a Vlčková et al. (2014) jsou však svým rozsahem a hloubkou analýzy spíše výjimkou a poskytují zatím pouze dílčí informace o úrovni motivace žáků k učení se cizím jazykům/angličtině a jejím vztahu ke studijním výsledkům.

\section{Cíl studie a vízkumné otázky}

Poznatků týkajících se motivace k učení se anglickému jazyku u českých žáků je v současné odborné literatuře poměrně málo. Motivace žáků k učení se cizím jazykům se může lišit na základě jejich charakteristik, at' už se jedná o pohlaví, věk či typ vzdělávací instituce, na které jedinec studuje. Hlubší poznání toho, jak se motivace k učení se anglickému jazyku liší na základě těchto a dalších charakteristik u českých žáků, je žádoucí, avšak ucelený přehled o těchto rozdílech v motivaci chybí. Také chybí dostatečné poznatky o tom, jaká je souvislost mezi úrovní motivace k učení se anglickému jazyku a studijními výsledky a aspiracemi u různých skupin žáků.

V této studii se snažíme přispět k zaplnění této mezery ve výzkumu skrz analýzu míry výkonové motivace v oblasti anglického jazyka u žáků základních škol různého pohlaví a jejího vztahu s: (1) známkou z anglického jazyka na vysvědčení (indikátor blízce související s výkonem v hodinách angličtiny), (2) získáním či nezískáním vyznamenání na vysvědčení (indikátor související s obecným výkonem $\mathrm{v}$ různých vyučovacích předmětech) a (3) budoucími studijními aspiracemi (indikátor orientovaný do budoucna, související s další vzdělávací dráhou žáků).

Cílem studie je tedy zjistit, jaký je vztah mezi úrovní výkonové motivace $\mathrm{v}$ angličtině a sledovanými indikátory u chlapců a dívek z vybraných základních škol v České republice. 
Konkrétně si klademe tyto výzkumné otázky:

1. Jaký je vztah mezi úrovní potřeby úspěšného výkonu $\mathrm{v}$ angličtině a potřeby vyhnutí se neúspěchu v angličtině a známkou na vysvědčení $\mathrm{z}$ anglického jazyka u chlapců a dívek?

2. Jaký je vztah mezi úrovní potřeby úspěšného výkonu $v$ angličtině a potřeby vyhnutí se neúspěchu $\mathrm{v}$ angličtině a získáním vyznamenání na vysvědčení u chlapců a dívek?

3. Jaký je vztah mezi úrovní potřeby úspěšného výkonu $\mathrm{v}$ angličtině a potřeby vyhnutí se neúspěchu $\mathrm{v}$ angličtině a budoucími studijními aspiracemi u chlapců a dívek?

\section{Metody}

Autoři výzkumu využívají data z rozsáhlého dotazníkového a testového šetření realizovaného na základních školách (v 9. ročnících) z Jihomoravského kraje v letech 2013 až 2014 (Vlčková et al., 2014).

\section{Výzkumný vzorek}

Školy byly ve výzkumném šetření vybrány náhodně na základě seznamu základních škol s úplným druhým stupněm $\mathrm{v}$ Jihomoravském kraji. $\mathrm{V}$ daných školách pak byly zahrnuty všechny třídy na úrovni devátého ročníku a všichni žáci v daných tř́dách, resp. jazykových skupinách. Z původně oslovených 26 škol se jich výzkumu zúčastnilo 16 (25 tř́íd, celkem 462 žáků). Pro účely této studie bylo z celkového vzorku zahrnuto 324 žáků (172 dívek, 152 chlapců), kteří v dotazníku uvedli veškeré údaje užité pro účely další analýzy.

\section{Metody sbèru dat a výžkumné nástroje}

Dotazník výkonové motivace

Výkonová motivace žáků byla měřena dotazníkem výkonové motivace MV - 6 Ž (Hrabal \& Pavelková, 2010). Znění položek původního dotazníku bylo mírně upraveno tak, aby odpovídalo situaci ve výuce anglického jazyka (konkrétní znění upravených položek dotazníku mủže čtenář nalézt v Příloze). V námi použitém dotazníku je PÚV měřena pomocí 7 položek (např. Ve výuce angličtiny se blásim: (a) vžddycky, když je to možné; (b) často; (c) někedy; (d) málokdy; (e) téměr nikedy) a PVN též pomocí 7 položek (např. Když mám být v angličtině zkoušnný, mám strach: (a) téměr vždy; (b) většinou; (c) někedy; (d) málokdy; (e) téměr nikdy). 
Tabulka 1

Základni deskriptivni údaje pro sebehodnoceni výkonových potřeb respondentu

\begin{tabular}{|l|c|c|c|c|c|}
\hline & \multicolumn{5}{|c|}{ Škálové kategorie (\%) } \\
\hline Položky dotazníku & 1 & 2 & 3 & 4 & 5 \\
\hline PÚV1 (vynikající žák) & 2,5 & 7,7 & 32,1 & 36,7 & 21,0 \\
\hline PÚV2 (dobré známky) & 0,9 & 3,7 & 37,7 & 37,0 & 20,7 \\
\hline PÚV3 (soustředění při učení) & 2,8 & 9,9 & 38,0 & 36,7 & 12,7 \\
\hline PÚV4 (pečlivost při učení) & 2,2 & 14,2 & 54,3 & 25,3 & 4,0 \\
\hline PÚV5 (hlášení se ve výuce) & 11,1 & 22,5 & 36,7 & 22,5 & 7,1 \\
\hline PÚV6 (známkování z předmětu) & 5,6 & 13,9 & 51,9 & 25,0 & 3,7 \\
\hline PÚV7 (zkoušení při nerozhodné známce) & 9,3 & 8,3 & 19,1 & 23,5 & 39,8 \\
\hline PVN8 (strach ze zkoušení) & 15,1 & 17,9 & 19,4 & 23,8 & 23,8 \\
\hline PVN9 (strach z předmětu) & 31,5 & 33,3 & 22,5 & 8,6 & 4,0 \\
\hline PVN10 (psaní písemky) & 20,4 & 37,3 & 24,7 & 9,3 & 8,3 \\
\hline PVN11 (zkoušení při nízkých znalostech) & 10,8 & 26,9 & 27,2 & 21,6 & 13,6 \\
\hline PVN12 (strach při cestě do školy) & 49,1 & 23,5 & 14,8 & 8,6 & 4,0 \\
\hline PVN13 (strach ze špatných známek) & 15,7 & 21,0 & 34,6 & 15,7 & 13,0 \\
\hline PVN14 (očekávaná známka z písemky) & 9,9 & 20,7 & 27,8 & 23,1 & 18,5 \\
\hline Indexy výkonové motivace & Průměr & SD & Min & Max & N \\
\hline iPÚV - celý soubor & 3,39 & 0,63 & 1,43 & 4,86 & 324 \\
\hline iPÚV - chlapci & 3,33 & 0,62 & 1,43 & 4,86 & 152 \\
\hline iPÚV - dívky & 3,45 & 0,64 & 1,43 & 4,86 & 172 \\
\hline iPVN - celý soubor & 2,71 & 0,90 & 1,00 & 4,71 & 324 \\
\hline iPVN - chlapci & 2,51 & 0,89 & 1,00 & 4,57 & 152 \\
\hline iPVN - dívky & 2,89 & 0,88 & 1,00 & 4,71 & 172 \\
\hline
\end{tabular}

Pozn.: PÚV = potřeba úspěšného výkonu, PVN = potřeba vyhnutí se neúspěchu, iPÚV = index potřeby úspěšného výkonu v angličtině, iPVN = index potřeby vyhnutí se neúspěchu $\mathrm{v}$ angličtině, $\mathrm{SD}=$ směrodatná odchylka. Znění konkrétních dotazníkových položek (PÚV1 až PVN14) je k dispozici v Př́loze. Škálové kategorie (a) odpovídají hodnotě 5 v tabulce (vyšší míra dané výkonové potřeby) a škálové kategorie (e) odpovídají hodnotě $1 \mathrm{v}$ tabulce (nižší míra dané výkonové potřeby).

Položky dotazníku jsou vybaveny 5 bodovými hodnoticími škálami. Odpovědi žáků byly pro účely analýzy kódovány tak, že škálové kategorie (a) odpovídaly hodnotě 5 (vyšší míra dané výkonové potřeby) a škálové kategorie (e) odpovídaly hodnotě 1 (nižší míra dané výkonové potřeby). Pro každého žáka počítáme index iPÚV (pro potřebu úspěšného výkonu $\mathrm{v}$ angličtině) a index iPVN (pro potřebu vyhnutí se neúspěchu v angličtině) jako průměr 
jeho odpovědí na 5 bodových škálách na dané dotazníkové položky. Indexy mohou nabývat hodnot 1 až 5, vyšší hodnoty odpovídají vyšším hodnotám potřeby úspěšného výkonu a potřeby vyhnutí se neúspěchu $v$ angličtině. Základní deskriptivní údaje pro sebehodnocení výkonových potřeb respondentů může čtenář nalézt $\mathrm{v}$ tabulce 1 .

Vybrané studijní výsledky, studijní aspirace a pohlaví žáků Mezi sledovanými indikátory byla žáky reportovaná známka z anglického jazyka na posledním vysvědčení. Původní hodnoty reprezentující známky $(1,2,3,4,5)$, které žáci udávali v rámci dotazníku, byly pro účely analýzy překódovány jako dummy proměnná známka z. $A J-1$, kde hodnota 1 znamená, že žák měl na vysvědčení $z$ angličtinu jedničku, hodnota 0 pak znamená, že žák měl některou ze zbývajících známek $(2,3,4,5)$.

V rámci dotazníku žáci dále reportovali (ano/ne), zdali měli na posledním vysvědčení vyznamenání. Pro účely analýzy tedy užíváme proměnnou vyzৃamenání, kde hodnota 1 znamená, že žák měl vyznamenání, hodnota 0 pak znamená, že žák vyznamenání neměl.

Tabulka 2

Zákeladni údaje pro vybrané studijni výsledky, studijni aspirace a poblavi žák.u

\begin{tabular}{|l|c|c|c|c|}
\hline & \multicolumn{4}{|c|}{ Hodnoty } \\
\hline Proměnná & \multicolumn{2}{|c|}{0} & 114 & $(35,2)$ \\
\hline Známka z AJ -1 & 210 & $(64,8)$ & 110 & $(40,1)$ \\
\hline Vyznamenání & 194 & $(59,9)$ & 130 & $(22,5)$ \\
\hline Po Ž́ - gymnázium & 251 & $(77,5)$ & 73 & $(46,9)$ \\
\hline Pohlaví - muž & 172 & $(53,1)$ & 152 & \\
\hline
\end{tabular}

Pozn.: Hodnoty v závorkách značí relativní četnost v procentech.

Žáci měli v rámci dotazníku rovněž uvést, zdali by po základní škole chtěli jít (a) na gymnázium, (b) na střední odbornou školu, (c) na učiliště či (d) do

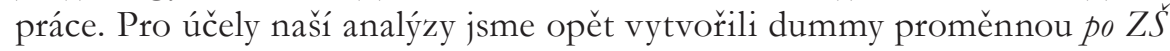
- gymnázium, kde hodnota 1 znamená, že žák chce jít po konci základní školy na gymnázium, hodnota 0 pak znamená, že žák chce jít na střední odbornou školu, učiliště, anebo do práce.

Z charakteristik žáků pak pracujeme s proměnnou poblaví - mǔ̌, kde hodnota 1 označuje žáka (chlapce), hodnota 0 žákyni (dívku). Základní údaje pro tyto proměnné jsou prezentovány v tabulce 2 . 


\section{Analýza dat}

Data byla analyzována pomocí softwaru R. Modely logistické regrese byly počítány pomocí funkce glm se specifikací probit. Vysvětlovanými proměnnými v těchto modelech jsou postupně známka z. AJ - 1, vyznamenání a po $Z S ̌ S-$ gymnázium. Vysvětlující proměnné jsou iPÚV, iPVN a poblaví- muそ̌. Model 1 pro každou z vysvětlovaných proměnných obsahuje pouze tyto tři vysvětlující proměnné bez analýzy vzájemných interakcí, model 2 pak zahrnuje i interakce mezi iPÚV a pohlaví - muž a dále mezi iPVN a poblaví - muž. Na základě modelu 2 pro každou z vysvětlovaných proměnných pak byla dále odhadnuta pravděpodobnost (uváděna $\mathrm{v} \%$ ), s jakou žák s danými průměrnými hodnotami potřeby úspěšného výkonu a potřeby vyhnutí se neúspěchu v angličtině dosáhne dané známky z angličtiny, vyznamenání či má danou studijní aspiraci. 'Tyto pravděpodobnosti jsou prezentovány zvlášt' pro dívky a zvlášt' pro chlapce.

\section{Výsledky}

Výsledky logistické regresní analýzy potvrzují existenci signifikantního vztahu mezi složkami výkonové motivace v anglickém jazyce a vybranými studijními výsledky a aspiracemi ${ }^{1}$ žáků (tabulka 3). V př́ípadě známky na vysvědčení z anglického jazyka (model 1) vidíme, že iPÚV je signifikantním pozitivním prediktorem (žáci s vyšší úrovní potřeby úspěšného výkonu v angličtině mají vyšší pravděpodobnost získat jedničku) a iPVN je signifikantním negativním prediktorem (žáci s nižší úrovní potřeby vyhnutí se neúspěchu

V rámci statistického vyhodnocení jsme provedli regresní analýzu, ve které byla proměnná pro studijní aspirace žáků zahrnuta v původní podobě $(1$ = práce, 2 = učiliště, 3 = střední odborná škola, 4 = gymnázium). V tomto modelu byly všechny koeficienty pro vysvětlující proměnné signifikantní a se stejnou polaritou jako v rámci logistické regrese prezentované v článku (iPÚV kladný, iPVN a poblaví - mužzáporné). Taktéž jsme provedli regresi, v rámci které byly porovnány dvě skupiny: (1) žáci uvádějící aspiraci studovat na gymnáziu nebo střední odborné škole a (2) žáci uvádějící aspiraci studovat na odborném učilišti nebo s ambicí nastoupit do práce. V tomto modelu byl efekt potřeby vyhnutí se neúspěchu výrazně menší, nicméně na hladině významnosti 10 \% stále signifikantní. Potřeba úspěšného výkonu v angličtině, potřeba vyhnutí se neúspěchu $\mathrm{v}$ angličtině a pohlaví tedy hrají signifikantní roli v ambici jít po základní škole alespoň na střední odbornou školu, nicméně potřeba vyhnutí se neúspěchu má věcně slabší efekt než v př́padě, kdy porovnáváme ambici studovat na gymnáziu oproti ambici studovat na střední odborné škole, odborném učilišti nebo jít do práce. 
$\mathrm{v}$ angličtině mají vyšší pravděpodobnost získat jedničku). Efekt pro poblaví - mu气̌je zde také signifikantní a negativní - jedničku na vysvědčení tedy mají vyšší pravděpodobnost získat dívky.

Po zařazení interakcí (známka z. $A J$ - 1, model 2) mezi pohlavím a jednotlivými potřebami zůstávají iPÚV a iPVN signifikantními prediktory známky $\mathrm{v}$ anglickém jazyce. Efekt pro jednotlivé interakce je pak statisticky nesignifikantní, nicméně regresní koeficienty jsou relativně vysoké $(\beta=-0,392$, $p=0,176$ pro poblavi - muž $\times$ iPÚV; $\beta=-0,251, p=0,205$ pro pohlavi - muž $\times$ iPVN). Pozitivní efekt potřeby úspěšného výkonu v angličtině na známku $z$ angličtiny je v průměru nižší pro chlapce než pro dívky. Naopak negativní efekt potřeby vyhnutí se neúspěchu v angličtině na známku z angličtiny je pro chlapce $v$ průměru vyšší. Výsledky tedy naznačují existenci rozdílů ve vztahu mezi jednotlivými složkami výkonové motivace v oblasti anglického jazyka a výsledky žáků v anglickém jazyce pro chlapce a dívky.

Tabulka 3

Regresni koeficienty pro známku z. angličtiny, ziskáni vyznamenáni na vysvédčeni a aspiraci studovat na gymnáziu jako vysvětlované promènné a výkonovou motivaci a poblavi žákư jako vysuétlujicí promènné

\begin{tabular}{|l|c|c|c|c|c|c|}
\hline & \multicolumn{2}{|c|}{ Známka z AJ - 1 } & \multicolumn{2}{c|}{ Vyznamenání } & \multicolumn{2}{c|}{ Po Ž̌ - gymnázium } \\
\hline & Model 1 & Model 2 & Model 1 & Model 2 & Model 1 & Model 2 \\
\hline Intercept & $-1,723^{* *}$ & $-2,851^{* * *}$ & $-1,569^{* *}$ & $-2,566^{* *}$ & $-0,916$ & $-1,649^{*}$ \\
\hline & $(0,588)$ & $(0,861)$ & $(0,558)$ & $(0,790)$ & $(0,612)$ & $(0,810)$ \\
\hline iPÚV & $0,827^{* * *}$ & $1,047^{* * *}$ & $0,694^{* * *}$ & $0,850^{* * *}$ & $0,387^{* *}$ & $0,513^{* *}$ \\
\hline & $(0,142)$ & $(0,204)$ & $(0,132)$ & $(0,181)$ & $(0,139)$ & $(0,181)$ \\
\hline iPVN & $-0,503^{* * *}$ & $-0,378^{* *}$ & $-0,282^{* *}$ & $-0,124$ & $-0,335^{* * *}$ & $-0,232^{\dagger}$ \\
\hline & $(0,097)$ & $(0,130)$ & $(0,089)$ & $(0,121)$ & $(0,100)$ & $(0,124)$ \\
\hline Pohlaví-muž & $-0,426^{* *}$ & 1,538 & $-0,682^{* * *}$ & 1,117 & $-0,744^{* * *}$ & 0,910 \\
\hline & $(0,165)$ & $(1,153)$ & $(0,158)$ & $(1,094)$ & $(0,177)$ & $(1,193)$ \\
\hline $\begin{array}{l}\text { Pohlaví- muž } \\
\times \text { iPÚV }\end{array}$ & & $-0,392$ & & $-0,269$ & & $-0,285$ \\
\hline & & $(0,290)$ & & $(0,269)$ & & $(0,287)$ \\
\hline $\begin{array}{l}\text { Pohlaví- muž } \\
\times \text { iPVN }\end{array}$ & $-0,251$ & & $-0,336^{\dagger}$ & & $-0,273$ \\
\hline & & $(0,199)$ & & $(0,185)$ & & $(0,217)$ \\
\hline $\mathrm{R}^{2}$ & 0,193 & 0,202 & 0,148 & 0,157 & 0,115 & 0,121 \\
\hline
\end{tabular}

Pozn.: Hodnoty v závorkách jsou standardní chyby. Hodnoty $\mathrm{R}^{2}$ odpovídají McFaddenovu $\mathrm{R}^{2}$. *** $p<0,001 ; * * p<0,01 ;{ }^{*} p<0,05 ;{ }^{\dagger} p<0,10$. 
Pravděpodobnosti získání jedničky na vysvědčení při daných průměrných hodnotách iPÚV a iPVN jsou prezentovány v tabulce 4 , v níž jsou prezentovány výsledky pouze pro průměrné hodnoty 2 až 4 obou indexů, což jsou hodnoty blízké průměrným hodnotám $\mathrm{v}$ našem výzkumném souboru (viz deskriptivní údaje pro oba indexy v tabulce 1$)$. Z výsledků vidíme, že existují rozdíly v pravděpodobnostech pro dívky a chlapce. Naprríklad $\mathrm{v}$ ŕádku 4 (iPÚV $=3$, iPVN = 2) ve sloupci známka ₹.AJ - 1 je pravděpodobnost získat jedničku vyšší pro dívky $(32,1 \%)$ než pro chlapce $(28,7 \%)$.

Pokud jde o vyznamenání na posledním vysvědčení, vidíme, že výsledky logistické regrese poskytují podobné výsledky jako v prŕípadě známky na vysvědčení z anglického jazyka. Model 1 ukazuje, že potřeba úspěšného výkonu je pozitivním a signifikantním prediktorem (žáci s vyšší hodnotou iPÚV mají vyšší pravděpodobnost získat vyznamenání) a potřeba vyhnutí se neúspěchu je signifikantním negativním prediktorem pro vyznamenání (žáci s vyšší hodnotou iPVN mají nižší pravděpodobnost získat vyznamenání). Podobně jako $v$ př́padě známky $z$ angličtiny, i zde mají chlapci signifikantně nižší pravděpodobnost získání vyznamenání.

Po přidání interakcí mezi pohlavím žáků a výkonovými potřebami do regresního modelu (vyžnamenání, model 2) vidíme, že zatímco iPÚV zůstává signifikantním prediktorem vyznamenání, hodnota pro koeficient iPVN se zredukuje a stává se nesignifikantní. Efekty pro interakce jsou relativně vysoké $(\beta=-0,269, p=0,318$ pro poblavi - muž $\times$ iPÚV; $\beta=-0,336, p<0,10$ pro pohlaví-muž $\times$ iPVN) a interakce mezi pohlavím a potřebou vyhnutí se neúspěchu je signifikantní na hladině významnosti $10 \%$. Tyto výsledky opět ukazují na komplexnější strukturu vztahů mezi motivačními potřebami a studijními výsledky mezi chlapci a dívkami, kdy je pozitivní efekt potřeby úspěšného výkonu $v$ angličtině pro chlapce nižší a negativní efekt potřeby vyhnutí se neúspěchu v angličtině naopak vyšší.

Pohled na tabulku pravděpodobností (tabulka 4, sloupec vyznamenání) pak opět ilustruje rozdíly v pravděpodobnostech mezi chlapci a dívkami, kdy např́klad v řádku 5 (iPÚV $=3$, iPVN = 3) mají vyšší pravděpodobnost získat vyznamenání dívky (34,9\%) oproti chlapcům (13,9\%).

Výsledky logistické regresní analýzy pro aspirace žáků po základní škole (model 1) ukazují, že jak iPÚV, tak iPVN jsou signifikantními prediktory studijních aspirací žáků. Vyšší hodnota potřeby úspěšného výkonu v angličtině tak zvyšuje pravděpodobnost, že daný žák bude aspirovat na studium na gymnáziu, a vyšší hodnota potřeby vyhnutí se neúspěchu $\mathrm{v}$ angličtině tuto pravděpodobnost snižuje. Efekt pohlaví je negativní a signifikantní, chlapci tedy mají nižší pravděpodobnost, že budou aspirovat na studium na gymnáziu. 
Po přidání interakcí pohlaví a výkonových potřeb v angličtině do regresního modelu ( po Ž́ - gymnázium, model 2) vidíme, že jak iPÚV, tak i iPVN zůstávají (ačkoliv iPVN pouze na hladině významnosti $10 \%$ ) signifikantními prediktory aspirace studovat na gymnáziu a dále že ani jedna z interakcí nedosahuje signifikance $(\beta=-0,285, p=0,321$ pro poblaví - muž $\times$ iPÚV; $\beta=-0,273, p=0,209$ pro poblaví- muž $\times$ iPVN). Regresní koeficienty pro tyto interakce však odpovídají těm, které byly nalezeny u předchozích vysvětlovaných proměnných, a naznačují, že pozitivní efekt potřeby úspěšného výkonu $\mathrm{v}$ angličtině je pro chlapce nižší a naopak negativní efekt potřeby vyhnutí se neúspěchu v angličtině je pro chlapce vyšší. Tato struktura vzájemných vztahů mezi výkonovou motivací v angličtině a vybranými studijními výsledky a studijními aspiracemi žáků při zohlednění jejich pohlaví je tak stejná např́íč všemi sledovanými indikátory.

Tabulka 4

Pravděpodobnosti pro známku zangličtiny, ziskáni vyznamenáni na vysvédčeni a aspiraci studovat na gymnáziu pri daných primèrných hodnotách potreby úspěsného výkonu a potreby vyhnutí se neúspéchu

\begin{tabular}{|l|c|c|c|c|c|c|c|c|}
\hline \multirow{2}{*}{} & \multirow{2}{*}{ iPÚV } & \multirow{2}{*}{ iPVN } & \multicolumn{2}{|c|}{ Známka z AJ - } & \multicolumn{2}{c|}{ Vyznamenání } & \multicolumn{2}{c|}{ Po ZŠ-gymnázium } \\
\cline { 4 - 9 } & 2 & 2 & 11,2 & 6,5 & 11,4 & 13,3 & 9,8 & 13,9 \\
\hline 1 & 2 & 3 & 3,2 & 2,9 & 4,8 & 10,8 & 3,6 & 9,4 \\
\hline 2 & 2 & 4 & 0,7 & 1,2 & 1,7 & 8,7 & 1,1 & 6,0 \\
\hline 3 & 3 & 2 & 28,7 & 32,1 & 26,6 & 39,6 & 14,4 & 28,3 \\
\hline 4 & 3 & 3 & 11,7 & 19,9 & 13,9 & 34,9 & 5,8 & 21,0 \\
\hline 5 & 3 & 4 & 3,4 & 11,1 & 6,1 & 30,5 & 1,9 & 14,9 \\
\hline 6 & 4 & 2 & 53,7 & 71,9 & 48,3 & 72,1 & 20,2 & 47,6 \\
\hline 7 & 4 & 3 & 29,5 & 58,0 & 30,8 & 67,8 & 9,0 & 38,5 \\
\hline 8 & 4 & 4 & 12,2 & 43,1 & 16,8 & 63,3 & 3,2 & 30,0 \\
\hline 9 & & & & & & & & \\
\hline
\end{tabular}

Pozn.: Hodnoty ve sloupcích iPÚV a iPVN reprezentují průměrné hodnoty daných motivačních potřeb. Uváděné simulované pravděpodobnosti na základě modelů 2 pro jednotlivé proměnné jsou v procentech.

Pokud jde o pravděpodobnosti aspirace na studium na gymnáziu při daných průměrných hodnotách iPÚV a iPVN (tabulka 4, sloupec po ZŠ-gymnázium), rozdíly mezi dívkami a chlapci mohou být ilustrovány např́klad v řádku 4 (iPÚV = 3, iPVN = 2), kdy mají vyšší pravděpodobnost této aspirace dívky $(28,3 \%)$ oproti chlapcům $(14,4 \%)$. 
Celková síla modelů je největší pro indikátor blízce související s výkonem v hodinách angličtiny (známka na vysvědčení z anglického jazyka), o něco menší pro indikátor související s obecným výkonem $\mathrm{v}$ různých vyučovacích předmětech (získání vyznamenání na vysvědčení) a nejmenší pro indikátor, který je orientován do budoucna a souvisí s další vzdělávací dráhou žáků (studijní aspirace žáků po základní škole).

\section{Diskuze}

Výsledky naší analýzy ukázaly, že existuje vztah mezi reportovanou motivací $\mathrm{k}$ učení se angličtině a známkou na vysvědčení z angličtiny, což je v souladu s předcházející literaturou (např. Khodadady \& Khajavy, 2013; Pae, 2008). Dále jsme však také nalezli, že potřeba úspěšného výkonu v angličtině je pozitivním prediktorem a potřeba vyhnutí se neúspěchu $v$ angličtině negativním prediktorem i dalších indikátorů na straně žáků, které se přímo nevážou na anglický jazyk jako takový - získání vyznamenání na vysvědčení a aspirace pokračovat ve studiu na gymnáziu.

Možným vysvětlením těchto zjištění je, že námi upravené položky směřující na výkonovou motivaci žáků v oblasti angličtiny zachycují obecnější dimenzi této motivace, poprrípadě že námi zachycovaná úroveň výkonové motivace $\mathrm{v}$ angličtině $\mathrm{s}$ touto obecnější dimenzí motivace souvisí. Je tedy možné, že žák, který reportuje, že se ve výuce angličtiny hlásí vždycky, když je to možné, je obecně motivovaný a snaživý žák, jenž se často hlásí i v jiných předmětech. To pak může vést $\mathrm{k}$ celkové vyšší úspěšnosti takového žáka, která se odráží v jeho vysvědčení a studijních aspiracích.

Výkonová motivace je zpravidla zkoumána bez přímé návaznosti na některou obsahovou oblast (např. školní předmět) a ucelených poznatků z doménově specifických aplikací je zatím spíše poskrovnu (Sparfeldt \& Rost, 2011). Dosavadní literatura naznačuje, že doménově orientované nástroje výkonové motivace žáků lépe predikují doménově specifické indikátory výkonu než obecně orientované nástroje (pro diskuzi viz např. Michel et al., 2020).

Naše analýza interakcí mezi pohlavím žáků a výkonovými potřebami $\mathrm{v}$ angličtině ukázala komplexnější strukturu ve vztazích mezi výkonovou motivací v angličtině a vybranými studijními výsledky a aspiracemi pro chlapce a dívky. Pro chlapce byl pozitivní efekt potřeby úspěšného výkonu $\mathrm{v}$ angličtině na tyto ukazatele nižší než pro dívky a naopak negativní efekt potřeby vyhnutí se neúspěchu $\mathrm{v}$ angličtině vyšší. Ačkoliv tak interakce obvykle nedosahovaly v regresních modelech statistické signifikance, velikost koeficientů byla v průměru vysoká.

Pavelková (2005) poskytuje přehled dosavadních výzkumných zjištění identifikujících rozdíly v různých typech motivace u českých žáků. Tato před- 
chozí šetření jed nak ukazují na důležitost výkonové motivace jako pohnutky $\mathrm{k}$ učení u žáků, ale rovněž naznačují, že tuto motivaci uváději častěji děvčata. U dívek se častěji objevovaly pohnutky spadající právě do výkonové motivace (např. dobrý pocit, když se něco naučím; snaha překonávat sám sebe; školní úkoly beru jako výzvu). U pohnutky obavy z neúspěchu pak bud’to nebyl nalezen rozdíl mezi dívkami a chlapci, nebo tuto pohnutku uváděly častěji dívky. Meece et al. (2006) se ve své přehledové studii zaměřují na rozdíly ve výkonové motivaci mezi žáky různého pohlaví. Dosavadní výzkum, vycházející z různých teoretických proudů, ukazuje převážně na rozdíly $\mathrm{v}$ přesvědčeních a hodnotách vážících se $\mathrm{k}$ výkonové oblasti mezi chlapci a dívkami. Autoři těchto výzkumů pak poukazují na to, že tyto rozdíly jsou často doménově specifické a že zatímco chlapci mívají pozitivní výkonová př́esvědčení $\mathrm{v}$ oblasti matematiky, přírodních věd (science) a sportu, dívky v tomto ohledu dopadají lépe v oblasti jazyků a čtení.

Naše výsledky tak přispívají k poznání genderových rozdílů ve složkách výkonové motivace právě ve specifické oblasti jazykủ (angličtiny). Dívky mohou být $\mathrm{v}$ této oblasti výrazněji výkonově zaměřené a potřeba úspěšného výkonu v angličtině tak pro ně může být silnějším prediktorem studijních výsledků a aspirací. Naopak potřeba vyhnutí se neúspěchu $v$ angličtině mủže být silnějším prediktorem studijních výsledků a aspirací pro chlapce. Potvrzení námi nalezené struktury vztahů však vyžaduje další výzkum, jenž by v budoucnu mohl zahrnout i další charakteristiky žáků, které se mohou vztahovat $\mathrm{k}$ úrovni a struktuře jejich motivace $\mathrm{k}$ učení se cizím jazykům.

Další bádání by rovněž mělo vzít $\mathrm{v}$ úvahu metodologické limitace při porovnávání různých skupin žáků. V našem výzkumu byl využit sebehodnoticí dotazník s položkami vybavenými hodnoticími škálami. V literatuře se však objevují pochybnosti o porovnatelnosti takto získaných dat z důvodů rozdílů v užívání škál mezi různými skupinami respondentů (např. Voňková, 2017). Dva respondenti se stejnou objektivní úrovní motivace mohou při odpovídání na dotazníkovou položku zaměřenou na jejich motivaci, např. Prí učeni angličtině jsem: a) hodně pečlivý; b) dost pečlivý; c) struedně pečlivú; d) málo pečlivý; e) viobec nejsem pečlivý, zvolit rozdílné škálové kategorie - jeden bodně pečlivý a druhý dost pečlivý. Tyto rozdíly pak mohou zkreslit výsledky, které na základě těchto dat obdržíme, a vést výzkumníky k mylným závěrům o objektivní úrovni motivace u různých (skupin) respondentů. He a Van de Vijver (2016) při porovnávání úrovně motivace $\mathrm{k}$ učení se matematice mezi žáky z různých zemí na základě dat ze studie Programme for International Student Assessment (PISA) z roku 2012 dokonce nalézají anomální negativní korelaci mezi úrovní motivace a školními výsledky žáků (země s nižší průměrnou úrovní motivace mají průměrně lepší výsledky v matematickém testu) a hovoří o tzv. motivačněvýkonovém paradoxu, který může být připsán právě rozdílům v užívání škál při reportování vlastní motivace u žáků z různých zemí. 
Pro identifikaci těchto rozdílů a následné očištění sebehodnocení respondentů o tyto rozdíly byly v literatuře navrženy různé metodologické př́stupy (Voňková, 2017). Jedním ze slibných prúístupů se jeví být metoda ukotvujících vinět (King et al., 2004). Ta je založena na principu, kdy respondenti nejen hodnotí sami sebe $\mathrm{v}$ rámci sebehodnoticích otázek $\mathrm{k}$ danému konceptu, ale hodnotí též sadu ukotvujících vinět - krátkých př́běhů popisujících hypotetické osoby s danou úrovní cílového konceptu. Př́íladem ukotvující viněty z oblasti motivace, které byly použity ve výzkumném šetření PISA 2015 v žákovském dotazníku (Česká školní inspekce, 2017), je: Přečti si charakteristiky následujicich trǔ žákư. Nakolik nesoublasíš nebo soublasišs na základě tèchto informaci s tvrženim, že je zále motivovaný? Kdy ̌̌ Franta narazi na problém, snadno se vz̨dává, a často nenípripraven na hodiny. Franta je motivovaný. 1) roz̧hodně nesoublasim; 2) nesoublasim; 3) soublasim; 4) roz̧hodnè soublasim.

Vzhledem k tomu, že všichni respondenti hodnotí stejné ukotvující viněty, mohou být rozdíly v jejich hodnocení interpretovány jako rozdíly v tom, jak užívají škálu. Pomocí této informace je pak možné „očistit“ jejich sebehodnocení s cílem získat lépe porovnatelné výsledky. Metoda poskytuje v pedagogickém výzkumu slibné výsledky a byla úspěšně aplikována např́ḱlad ve výzkumu školního nečestného chování žáků (Voňková et al., 2017) či úrovně učitelova řízení tř́́dy (Voňková et al., 2018; pro přehled aplikací viz Voňková et al., 2016). Pro budoucí výzkum žákovské motivace k učení se anglickému jazyku doporučujeme aplikovat metodu ukotvujících vinět s cílem zjistit, zdali v této oblasti existují systematické rozdíly v užívání škál mezi různými skupinami respondentů a nakolik mohou ty to rozdíly zkreslit výsledky.

\section{Závěr}

Cílem studie bylo zjistit, jaký je vztah mezi úrovní výkonové motivace $\mathrm{v}$ angličtině a vybranými studijními výsledky a aspiracemi u chlapců a dívek z vybraných základních škol v Jihomoravském kraji. Naše analýza ukázala, že existuje vztah mezi výkonovou motivací v anglickém jazyce a těmito indikátory. Potřeba úspěšného výkonu v angličtině je pozitivním a signifikantním prediktorem všech tř́ sledovaných proměnných (známka z angličtiny na vysvědčení, získání vyznamenání na vysvědčení, budoucí aspirace studovat na gymnáziu), zatímco potřeba vyhnutí se neúspěchu je u všech těchto proměnných signifikantním negativním prediktorem. Bližší analýza těchto vztahů dle pohlaví žáků naznačuje, že pro chlapce je pozitivní efekt potřeby úspěšného výkonu $\mathrm{v}$ angličtině na vybrané studijní výsledky a aspirace nižší než pro dívky a naopak negativní efekt potřeby vyhnutí se neúspěchu v angličtině na ty to ukazatele vyšší. Potvrzení tohoto zjištění však vyžaduje další výzkum. 
Budoucí výzkum by se měl zaměřit na další charakteristiky žáků, jako je socioekonomický status, etnicita aj. Je možné, že míra motivace k učení se angličtině je u těchto skupin žáků odlišná, stejně tak jako úloha jednotlivých složek motivace ve vztahu $k$ jejich studijním výsledkům a aspiracím, podobně jako to naznačuje naše analýza $\mathrm{v}$ př́ípadě pohlaví žáků. Dále by bylo vhodné výzkum rozšíríit na žáky víceletých gymnázií a zahrnout také žáky jak z veřejných, tak i soukromých škol. V neposlední řadě by pak další výzkum měl, jak již bylo diskutováno výše, reflektovat možné rozdíly v užívání škál mezi různými skupinami respondentů a zařadit některé z metodologických př́stupů, které umožňují ty to rozdíly identifikovat a očistit tak žákovo sebehodnocení. Pro tento účel se zdá být vhodná zejména metoda ukotvujících vinět.

\section{Poděkování}

Studie vznikla v rámci řešení projektu GAČR Analýz̨a determinantů sebehodnoceni znalosti anglického jazyka a motivace k ureni se anglickému jazyku u českých žákio nižšího sekundárního stupně (20-05484S). Autoři děkují za podporu.

\section{Literatura}

Azarnoosh, M., \& Birjandi, P. (2012). Junior high school students' L2 motivational self system: Any gender differences. World Applied Sciences Journal, 20(4), 577-584. https://doi.org/10.5829/ idosi.wasj.2012.20.04.2732

Boo, Z., Dörnyei, Z., \& Ryan, S. (2015). L2 motivation research 2005-2014: Understanding a publication surge and a changing landscape. System, 55, 145-157. https://doi.org/10.1016/j. system.2015.10.006

Bronec, J. (1991). Motivace ve výuce cizích jazyků. Sborník praci Filozofické fakulty brnènské univerzity, 40(A39), 83-91.

Csizér, K., \& Dörnyei, Z. (2005). The internal structure of language learning motivation and its relationship with language choice and learning effort. The Modern Language Journal, 89(1), 19-36. https://doi.org/10.1111/j.0026-7902.2005.00263.x

Česká školní inspekce. (2017, 12. červen). Česká školní inspekce zueřjñuje národní a mezinárodní databázi šetrení PIS A 2015. https://www.csicr.cz/Prave-menu/Mezinarodni-setreni/PISA/ Datove-soubory-a-dotazniky/Ceska-skolni-inspekce-zverejnuje-narodni-a-mezinar

Dörnyei, Z. (2005). The psychology of the language learner: Individual differences in second language acquisition. Lawrence Erlbaum.

Dörnyei, Z. (2009). The L2 Motivational Self System. In Z. Dörnyei \& E. Ushioda (Eds.), Motivation, language identity and the L2 self (s. 9-42). Multilingual Matters.

Frydrychová Klímová, B. (2011). Motivation for learning English at a university level. Procedia Social and Behavioral Sciences, 15, 2599-2603. https://doi.org/10.1016/j.sbspro.2011.04.153

Frydrychová Klímová, B., \& Poulová, P. (2015). The role of ICT in raising student's motivation to learn English as a foreign language: Two case studies. In A. Jefferies \& M. Cubric (Eds.), Proceedings of the 14th European Conference on e-Learning (s. 293-298). University of Hertfordshire. 
Gardner, R. C. (1985). The Attitude/Motivation Test Battery: Technical report. University of Western Ontario. http://publish.uwo.ca/ gardner/docs/AMTBmanual.pdf

Gardner, R. C., Smythe, P. C., Clément, R., \& Gliksman, L. (1976). Second-language learning: A social psychological perspective. Canadian Modern Language Review, 32(3), 198-213. https:// doi.org/10.3138/cmlr.32.3.198

He, J., \& van de Vijver, F. J. R. (2016). The motivation-achievement paradox in international educational achievement tests: Toward a better understanding. In R. B. King \& A. B. I. Bernardo (Eds.), The psychology of Asian learners: A festschrift in honor of David Watkins (s. 253-268). Springer Science. https://doi.org/10.1007/978-981-287-576-1_16

Hrabal, V., \& Pavelková, I. (2010). Jakýj jsem učitel. Portál.

Janíková, V. (2016). Učení a vyučování cizích jazyků a identita. Pedagogická orientace, 26(1), 24-50. https://doi.org/10.5817/PedOr2016-1-24

Jedinák, D. (1993). Smerom k motivácii štúdia matematiky. Pedagogická orientace, 8-9(3), 59-69.

Khodadady, E., \& Khajavy, G. H. (2013). Exploring the role of anxiety and motivation in foreign language achievement: A structural equation modeling approach. Porta Linguarum, 20, 269-286. https://doi.org/10.30827/Digibug.20240

King, G., Murray, C., Salomon, J., \& Tandon, A. (2004). Enhancing the validity and crosscultural comparability of measurement in survey research. American Political Science Review, 98(1), 191-207. https://doi.org/10.1017/S000305540400108X

Knihová, L., \& Hronová, Š. (2015). Motivace ke studiu cizího jazyka a výuka angličtiny pro specifické účely v terciárním vzdělávání. In Sborník príspèvkè z meąinárodni védecké konference Evropské pedagogické fórum 2015: Prínosy, výzvy, očekáváni (s. 55-64). Magnanimitas.

Kong, J. H., Han, J. E., Kim, S., Park, H., Kim, Y. S., \& Park, H. (2018). L2 Motivational Self System, international posture and competitiveness of Korean CTL and LCTL college learners: A structural equation modeling approach. System, 72, 178-189. https://doi. org/10.1016/j.system.2017.11.005

Kormos, J., \& Csizér, K. (2008). Age-related differences in the motivation of learning English as a foreign language: Attitudes, selves, and motivated learning behavior. Language Learning, 58(2), 327-355. https://doi.org/10.1111/j.1467-9922.2008.00443.x

Kozáková, P. (2013). Motivační pohybové aktivity ve výuce ruského jazyka na druhém stupni ZŠ. In J. Konečný (Ed.), Pražská rusistika 2013: Recenzovaný sborník prǐspèvkè z konference konané dne 18. dubna 2013 v Praz̧e (s. 110-122). Pedagogická fakulta Univerzity Karlovy v Praze.

Kubíková, K., \& Kostelníková, M. (2017). Příčiny nízké motivace ke studiu německého jazyka na středních školách. In M. Pešková \& K. Kubíková (Eds.), Rozvíjení interkulturní komunikační kompetence ve výuce cizích jazykư 2 (s. 26-42). Západočeská univerzita v Plzni.

Lamb, M. (2017). The motivational dimension of language teaching. Language Teaching, 50(3), 301-346. https://doi.org/10.1017/S0261444817000088

Markus, H., \& Nurius, P. (1986). Possible selves. American Psychologist, 41(9), 954-969. https:// doi.org/10.1037/0003-066X.41.9.954

Meece, J. L., Glienke, B. B., \& Burg, S. (2006). Gender and motivation. Journal of School Psychology, 44(5), 351-373. https://doi.org/10.1016/j.jsp.2006.04.004

Michel, Y. A., Steinmayr, R., Frenzel, A. C., \& Ziegler, M. (2020). Unpacking domain-specific achievement motivation: The role of contextualising items for test-criterion correlations. Educational Psychology. Advance online publication. https://doi.org/10.1080/01443410.202 0.1713303

Mori, S., \& Gobel, P. (2006). Motivation and gender in the Japanese EFL classroom. System, 34(2), 194-210. https://doi.org/10.1016/j.system.2005.11.002 
Noels, K. A., Pelletier, L. G., Clément, R., \& Vallerand, R. J. (2000). Why are you learning a second language? Motivational orientations and self-determination theory. Language Learning, 50(1), 57-85. https://doi.org/10.1111/0023-8333.00111

Pae, T. I. (2008). Second language orientation and self-determination theory: A structural analysis of the factors affecting second language achievement. Journal of Language and Social Psychology, 27(1), 5-27. https://doi.org/10.1177/0261927X07309509

Papi, M. (2010). The L2 motivational self system, L2 anxiety, and motivated behavior: A structural equation modeling approach. System, 38(3), 467-479. https://doi.org/10.1016/j. system.2010.06.011

Pavelková, I. (2005). Postoje chlapců a dívek ke školním předmětům. In D. Heller, J. Procházková, \& I. Sobotková (Eds.), Psychologické dny 2004: Svèt žen a svět mužu: polarita a vájemné obohacováni: sbornike príspèvkư z. konference Psychologické dny, Olomouc 2004 (s. 1-10). Univerzita Palackého v Olomouci.

Pavelková, I., \& Frencl, M. (1997). Motivace žáků k učení. Pedagogika, 47(4), 329-345.

Pavelková, I., Hrabal, K., \& Hrabal, V. (2010). Mezinárodní srovnání motivačních zdrojů učební činnosti žáků. Pedagogika, 60(3-4), 97-107.

Pavlíková, S. (2015). Kvalitativní výzkum zaměřený na výuku odborného anglického jazyka na vysoké škole. ACC JOURNAL, 21(3), 47-55. https://doi.org/10.15240/tul/004/2015-3-005

Pecková, S. (2015). Fiktivní firma jako prostředek osvojování cizího jazyka - výzkumná zjištění. Business \& IT, 5(2), 80-89.

Smejkalová, K. (2016). Preference metody simulace a její vliv na percepci motivace a jazykové kompetence studentů. Paidagogos, 2016(1), 90-106.

Sparfeldt, J. R., \& Rost, D. H. (2011). Content-specific achievement motives. Personality and Individual Differences, 50(4), 496-501. https://doi.org/10.1016/j.paid.2010.11.016

Trna, J. (1996). Dovednost učitele motivovat žáka. Pedagogická orientace, 18-19(6), 58-63.

Vlčková, K. (2007). Strategie učení ciz̨imu jazyku: Výsledky výzkumu ponživáni strategii a jejich efektivity na gymnáziich. Paido.

Vlčková, K., Pešková, K., Uličná, K., Janík, M., \& Švejdíková, K. (2014). Žákovské strategie prì učeni se anglickému jazyku a jejich vそtah ke úspěšnosti. Masarykova univerzita. https://doi. org/10.5817/CZ.MUNI.M210-7595-2014

Voňková, H. (2017). Metoda ukotvujicich vinèt a její využití v pedagogickém výžkumu. Pedagogická fakulta, Univerzita Karlova.

Voňková, H., Bendl, S., \& Papajoanu, O. (2017). How students report dishonest behavior in school: Self-assessment and anchoring vignettes. The Journal of Experimental Education, 85(1), 36-53. https://doi.org/10.1080/00220973.2015.1094438

Voňková, H., Papajoanu, O., \& Bendl, S. (2016). Aplikace metody ukotvujících vinět v pedagogickém výzkumu: přehled literatury a metodologická doporučení. Pedagogická orientace, 26(3), 537-559. https://doi.org/10.5817/PedOr2016-3-537

Voňková, H., Zamarro, G., \& Hitt, C. (2018). Cross-country heterogeneity in students' reporting behavior: The use of the anchoring vignette method. Journal of Educational Measurement, 55(1), 3-31. https://doi.org/10.1111/jedm.12161

You, C. J., \& Dörnyei, Z. (2016). Language learning motivation in China: Results of a large-scale stratified survey. Applied Linguistics, 37(4), 495-519. https://doi.org/10.1093/applin/amu046

You, C., Dörnyei, Z., \& Csizér, K. (2016). Motivation, vision, and gender: A survey of learners of English in China. Language Learning, 66(1), 94-123. https://doi.org/10.1111/lang.12140 


\section{Kontakt na autory}

Ondřej Papajoanu

Katedra pedagogiky, Pedagogická fakulta, Univerzita Karlova

E-mail: ondrej.papajoanu@pedf.cuni.cz

Hana Voňková

Katedra pedagogiky, Pedagogická fakulta, Univerzita Karlova

E-mail: h.vonkova@gmail.com / hana.vonkova@pedf.cuni.cz

Kateřina Vlčková

Katedra pedagogiky, Pedagogická fakulta, Masarykova univerzita

E-mail:vlckova@ped.muni.cz

\section{Corresponding authors}

Ondřej Papajoanu

Department of Education, Faculty of Education, Charles University

E-mail: ondrej.papajoanu@pedf.cuni.cz

Hana Voňková

Department of Education, Faculty of Education, Charles University

E-mail: h.vonkova@gmail.com / hana.vonkova@pedf.cuni.cz

\section{Kateřina Vlčková}

Department of Education, Faculty of Education, Masaryk University

E-mail:vlckova@ped.muni.cz 


\section{Př́loha}

\section{Znění upravených položek dotazníku výkonové motivace v anglickém jazyce}

Zakroǔ̌kuj vždy jednu odpovéd', k.terá se pro Tebe nejvíc hodí.

Pracuj pokud možno rychle, nejde o to, jak se v angličtinè citiš, ale o Tvij prevažujicípocit.

\section{PÚV1}

Abych byl vynikajicim žákem v angličtinè, o to stojím:

a) moc; b) dost; c) strednè; d) moc ne; e) viubec ne

\section{PÚV2}

Dobré známky z angličtiny pro mě maji:

a) velmi vysokou bodnotu; b) vysokou bodnotu; c) někdy maji, někdy nemaji vysokou bodnotu; d) nemaji vysokou hodnotu; e) maji velmi malou bodnotu

\section{PÚV3}

Prí učeni angličtinè se mi daři soustredit:

a) témér vždy; b) často; c) někedy; d) vétšinou ne; e) témér nikdy

\section{PÚV4}

Pri učeni angličtinè jsem:

a) bodně pečlivý; b) dost pečlivý; c) středně pečlivý; d) málo pečlivý; e) viobec nejsem pečlivý

\section{PÚV5}

Ve výuce angličtiny se hlásím:

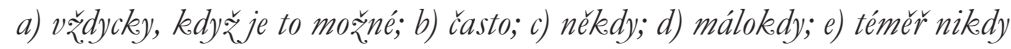

\section{PÚV6}

Kdybych si mohl vybrat, chtěl bych být v angličtinè známkovaný:

a) vždycky, kdy žje to možné; b) často; c) jen někdy; d) málokdy; e) témèr nikedy

PÚV7

Mám-li prèd vysvědčením nerozhodnou známku za angličtiny, príblásím se, abych byl vyz.koušen:

a) témér vと̌dy; b) vétšinou; c) někedy; d) málokddy; e) témér nikdy

\section{PVN8}

Když mám být $v$ angličtině zkoušený, mám strach:

a) témér vădy; b) vétšinou; c) někdy; d) málokdy; e) témér nikdy

\section{PVN9}

Mám-li být uprímný, tak se angličtiny jako vyučovacího predmètu:

a) bodně se bojim; b) dost bojim; c) trochu bojim; d) moc nebojim; e) viobec nebojim 
PVN10

Když máme psát pisemku z angličtiny:

a) mám téměr v v̌̌dycky chut’ nejit do školy; b) mám často chut' nejit do školy; c) mám nèkedy chut' nejit do školy; d) moc mi to nevadí; e) vỉbec mi to nevadí

\section{PVN11}

Kdyžjsem zkoušený z anglictiny a moc neumim:

a) mám vždycky pocit, že bych se nejraději sebral a odešel; b) mám často pocit, že bych se nejraději sebral a odešel;c) mám někdy takový pocit; d) nemívám vètšinou takový pocit;

e) nemivám takový pocit téměr nikdy

\section{PVN12}

Kdy乏̌jdu ráno do školy, mivám strach, jak to zase v angličtine dopadne:

a) téměr vǎddy; b) často; c) někedy; d) málokedy; e) téměr nikdy

\section{PVN13}

Špatných známek z. angličtiny se obávám:

a) bodně; b) dost; c) někedy ano, někedy ne; d) málo; e) vióbec

\section{PVN14}

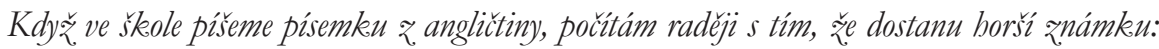

a) témér vždy; b) často; c) něeddy; d) málokddy; e) téměr nikdy 